\title{
STATUS KEPADATAN TULANG BERDASARKAN KATEGORI LINGKAR PINGGANG WANITA DEWASA
}

\author{
Citra Juliandari Ruseno, Hesti Murwani Rahayuningsih ${ }^{*}$ \\ Program Studi Ilmu Gizi Fakultas Kedokteran Universitas Diponegoro \\ Jl.Dr.Sutomo No.18, Semarang, Telp (024) 8453708, Email : gizifk@ undip.ac.id
}

\begin{abstract}
Background: Low bone density can be caused by high percent body fat; low intakes of calcium, vitamin D, protein; low physical activity; and sedentary life style. High waist circumference can be used as predictors of abdominal obesity. Abdominal obesity can lead to many degenerative diseases, one of them is osteoporosis.

Objective: The aim of this study is to analyze the difference of bone density between normal waist circumference and abdominal obesity, and to determine relationship percent body fat, calcium intake, vitamin D intake, protein intake, fat intake, and physical activity to bone density in adult female.

Method: An observational study with cross-sectional design held on Lamper Kidul, South Semarang. The subjects were 32 adult female aged 30-55 years old, comprised to 16 subjects with waist circumference $\leq 80 \mathrm{~cm}$ and 16 subjects with waist circumference $>80 \mathrm{~cm}$. Data of bone density was measured using ultrasound densitometer, data of waist circumference using metline, data of percent body fat using Bioelectrical Impedance Analyzer (BIA), data of nutrients intake (calcium, vitamin D, protein, fat) using a semi-quantitative food frequency questionnaire ( $F F Q$ ), and data of physical activity using IPAQ form. Bivariate analysis was used Chi-square test. Multivariate analysis was used logistic regression test.

Result: In the category of normal waist circumference, subjects with osteopenia were more (75\%) than subjects with normal bone density (25\%). Whereas, in the category of abdominal obesity, subjects with normal bone density were more $(56,3 \%)$ than subjects with osteopenia $(43,8 \%)$. There was no difference of bone density between normal waist circumference and abdominal obesity in adult female $(p=0,072)$. Physical activity has a strong relation to bone density after adjusted by fat intake and percent body fat $(p=0,014)$.

Conclusion: There was no difference of bone density between normal waist circumference and abdominal obesity in adult female. Physical activity has relation to bone density after adjusted by fat intake and percent body fat.

Keyword: bone density, waist circumference, percent body fat, calcium intake, vitamin D intake, protein intake, fat intake, physical activity, adult female
\end{abstract}

\begin{abstract}
ABSTRAK
Latar Belakang: Kepadatan tulang rendah disebabkan oleh persen lemak tubuh tinggi, asupan kalsium rendah, asupan vitamin D rendah, asupan protein rendah, aktivitas fisik rendah, dan gaya hidup sedentari. Lingkar pinggang besar dapat dijadikan prediktor obesitas abdominal. Obesitas abdominal dapat menimbulkan berbagai penyakit degeneratif, seperti osteoporosis.

Tujuan: Menganalisis perbedaan kepadatan tulang antara lingkar pinggang normal dan obesitas abdominal, serta mengetahui hubungan persen lemak tubuh, asupan kalsium, asupan vitamin D, asupan protein, asupan lemak, dan aktivitas fisik terhadap kepadatan tulang pada wanita.

Metode: Penelitian observasional dengan desain cross-sectional yang dilaksanakan di Kelurahan Lamper Kidul Kecamatan Semarang Selatan. Subjek penelitian adalah wanita dewasa usia 30-55 tahun sebanyak 32 subjek yang terdiri dari 16 subjek dengan lingkar pinggang $\leq 80 \mathrm{~cm}$ dan 16 subjek dengan lingkar pinggang $>80 \mathrm{~cm}$. Data kepadatan tulang diukur menggunakan densitometer ultrasound, data lingkar pinggang menggunakan metline, data persen lemak tubuh menggunakan Bioelectrical Impedance Analyzer (BIA), data asupan gizi (kalsium, vitamin D, protein, lemak) menggunakan kuesioner semi quantitative food frequency, dan data aktivitas fisik menggunakan formulir IPAQ. Analisis bivariat menggunakan uji Chi-Square. Analisis multivariat menggunakan uji regresi logistik. Hasil: Pada kategori lingkar pinggang normal, subjek dengan kepadatan tulang osteopenia lebih banyak (75\%) dibandingkan subjek dengan kepadatan tulang normal (25\%). Sedangkan pada kategori lingkar pinggang obesitas abdominal, subjek dengan kepadatan tulang normal lebih banyak $(56,3 \%)$ dibandingkan subjek dengan kepadatan tulang osteopenia $(43,8 \%)$. Tidak terdapat perbedaan kepadatan tulang antara kategori lingkar pinggang normal dan obesitas abdominal pada wanita dewasa (p=0,072). Aktivitas fisik memiliki hubungan paling kuat dengan kepadatan tulang setelah disesuaikan dengan asupan lemak dan persen lemak $(p=0,014)$.

Kesimpulan: Tidak ada perbedaaan kepadatan tulang antara kategori lingkar pinggang normal dan obesitas abdominal pada wanita dewasa. Aktivitas fisik berhubungan dengan kepadatan tulang setelah disesuaikan dengan asupan lemak dan persen lemak.
\end{abstract}

Kata kunci: kepadatan tulang, lingkar pinggang, persen lemak tubuh, asupan kalsium, asupan vitamin D, asupan protein, asupan lemak, aktivitas fisik, wanita dewasa

${ }^{*}$ Penulis Penanggungjawab 


\section{PENDAHULUAN}

Osteoporosis merupakan salah satu penyakit degeneratif berupa penurunan mikroarsitektur tulang secara progresif ditandai dengan penurunan kepadatan tulang yang menyebabkan peningkatan risiko patah tulang. ${ }^{1,2}$ International Osteoporosis Foundation (IOF) memperkirakan osteoporosis di Indonesia meningkat menjadi 288 juta pada tahun 2050 pada populasi di atas 60 tahun. ${ }^{3}$ Osteoporosis merupakan penyakit yang banyak terjadi pada wanita. World Health Organization (WHO) memaparkan bahwa kejadian patah tulang akibat osteoporosis lebih berisiko pada wanita sebanyak 40\%. Dampak ekonomi terhadap patah tulang akibat osteoporosis adalah penurunan produktivitas dan biaya mahal yang dikeluarkan untuk pengobatan., ${ }^{3,4}$

Perhimpunan Osteoporosis Indonesia (PEROSI) memaparkan $90 \%$ wanita mengalami osteopenia dan 32,3\% osteoporosis. ${ }^{3}$ Penelitian yang dilakukan di 3 provinsi, yaitu Sulawesi Utara, Yogyakarta, dan Jawa Barat menunjukkan risiko osteoporosis sebesar 22,3\% dan osteopenia sebesar 32,7\%. ${ }^{1}$ Dinas Kesehatan Kota Semarang memaparkan kejadian osteoporosis di Kota Semarang mencapai 1559 orang pada tahun 2012. ${ }^{5}$

Laju peningkatan kepadatan tulang paling cepat selama pertumbuhan remaja, setelah itu laju peningkatan relatif melambat hingga mencapai puncak kepadatan tulang pada akhir usia 20-30 tahun. Kepadatan tulang menurun sebanyak $1 \%$ per tahun saat mencapai masa menopause, meningkat $2 \%$ hingga $6 \%$ per tahun saat 1-5 tahun awal menopause. ${ }^{4}$

Beberapa faktor yang dapat menurunkan kepadatan tulang adalah wanita yang sudah mendekati masa premenopause, penggunaan obat seperti glukokortikoid selama 2 bulan atau lebih, merokok, konsumsi minuman beralkohol lebih dari 1 gelas per hari, aktivitas fisik rendah $<2000 \mathrm{kkal}$, asupan kalsium <1000 mg per hari, dan komposisi tubuh dengan massa lemak (fat mass) lebih besar dibanding massa bebas lemak (lean body mass). ${ }^{2,4,6}$ Massa bebas lemak merupakan komponen berat badan kecuali lemak, utamanya terdiri dari otot, tulang, dan cairan ekstraseluler. Massa lemak merupakan lemak tubuh penyusun berat badan. ${ }^{7}$ Wanita dewasa memiliki $12 \%$ lemak esensial, $15 \%$ simpanan lemak (total lemak tubuh 27\%), 36\% jaringan otot, $12 \%$ jaringan tulang, dan $25 \%$ komponen tubuh lainnya. ${ }^{8}$ Keadaan ketika massa lemak berlebih disimpan dalam jaringan adiposa disebut obesitas. Penelitian mengenai komposisi peningkatan berat badan menunjukkan massa bebas lemak sebesar $29 \%$ pada peningkatan berat badan orang obesitas. ${ }^{9}$ Obesitas dapat menimbulkan berbagai penyakit degeneratif, salah satunya adalah osteoporosis. ${ }^{10,11}$ Penelitian yang dilakukan tahun 2007 menunjukkan terdapat hubungan negatif antara kepadatan tulang dengan massa lemak. ${ }^{12}$

Lingkar pinggang dan persen lemak tinggi dapat dijadikan prediktor obesitas. Obesitas memiliki massa lemak lebih besar dibanding massa bebas lemak. Akan tetapi, massa lemak dan massa bebas lemak memiliki peran terhadap kepadatan tulang. Berat badan (termasuk massa lemak dan massa bebas lemak) memiliki hubungan positif dengan kepadatan tulang. ${ }^{9}$ Penelitian cross sectional pada wanita premenopause dan postmenopause yang memiliki persen lemak tinggi berhubungan dengan osteopenia. ${ }^{13}$

Jaringan lemak pada perut lebih banyak aktif secara metabolik memberi dampak negatif terhadap kepadatan tulang. Risiko patah tulang meningkat pada obesitas karena menurunnya kepadatan tulang. Penelitian yang dilakukan pada wanita premenopause di Cina menunjukkan risiko osteoporosis dan patah tulang $28,53 \%$ lebih besar pada subjek dengan persentase lemak berlebih. ${ }^{2,14}$

Obesitas menjadi masalah kesehatan di Indonesia terutama daerah perkotaan. Menurut data Riset Kesehatan Dasar (Riskesdas) tahun 2010, prevalensi obesitas pada orang dewasa meningkat menjadi $23,3 \%$. Prevalensi obesitas pada usia 40-44 tahun lebih besar dibandingkan kelompok usia lainnya. Prevalensi obesitas pada wanita lebih besar $(22,1 \%)$ dibanding pria $(10,7 \%){ }^{6}$

Berdasarkan uraian tersebut, peneliti tertarik menganalisis perbedaan kepadatan tulang antara lingkar pinggang normal dan obesitas abdominal, serta mengetahui hubungan persen lemak tubuh, asupan kalsium, asupan vitamin D, asupan protein, asupan lemak, dan aktivitas fisik terhadap kepadatan tulang pada wanita dewasa.

\section{METODE PENELITIAN}

Penelitian ini merupakan penelitian observasional dengan desain cross-sectional yang dilaksanakan di Kelurahan Lamper Kidul Kecamatan Semarang Selatan. Ruang lingkup penelitian ini termasuk ke dalam bidang gizi masyarakat. Populasi target yaitu seluruh wanita dewasa usia 30-55 tahun. Populasi terjangkau yaitu wanita dewasa usia 30-55 tahun di Kelurahan Lamper Kidul. Besar sampel dalam penelitian ini sebanyak 32 subjek yang terdiri dari 16 subjek dengan lingkar pinggang $\leq 80 \mathrm{~cm}$ dan 16 subjek dengan lingkar pinggang $>80 \mathrm{~cm}$.

Pengambilan sampel dilakukan dengan metode consecutive sampling dengan kriteria 
inklusi sudah menstruasi dan belum menopause, tidak dalam kondisi hamil, tidak memiliki kebiasaan merokok dan mengonsumsi minuman beralkohol, tidak memiliki penyakit yang mempengaruhi kepadatan tulang (osteoartritis, diabetes melitus, rheumatoid arthritis, hipertiroid, penyakit liver kronis), dan tidak sedang melakukan pengobatan atau mengonsumsi obat yang mempengaruhi kepadatan tulang (kortikosteroid, glukokortikoid, heparin), serta bersedia mengikuti penelitian melalui persetujuan Informed Consent dari awal hingga akhir penelitian. Subjek akan dikeluarkan dari penelitian bila tidak mengikuti setiap tahap penelitian, sakit atau meninggal dunia, dan berpindah tempat tinggal.

Variabel bebas dalam penelitian ini adalah lingkar pinggang. Variabel terikat yaitu kepadatan tulang. Beberapa variabel perancu yaitu persen lemak tubuh, asupan kalsium, asupan vitamin D, asupan protein, asupan lemak, dan aktivitas fisik.

Data lingkar pinggang diperoleh dari pengukuran lingkar pertengahan antara tepi inferior costa terbawah dengan crista iliaca, sementara subjek yang diukur berada dalam posisi berdiri pada saat akhir ekspirasi. Lingkar pinggang diukur dengan metline yang diletakkan pada kulit daerah abdomen tanpa alas kain. Kategori lingkar pinggang terdiri dari normal (LP $\leq 80 \mathrm{~cm})$ dan obesitas abdominal $(\mathrm{LP}>80 \mathrm{~cm})$.

Data kepadatan tulang diperoleh dari nilai pemeriksaan Bone Mineral Density (BMD) dinyatakan dalam T-score. Subjek duduk di kursi dengan menempatkan tulang tumit (tulang calcaneus) pada densitometer ultrasound. Pengukuran kepadatan tulang dilakukan oleh Team Bone Scan. Kategori kepadatan tulang terdiri dari normal ( $\mathrm{T} \geq-1,0 \mathrm{SD})$, osteopenia $(-1,0 \mathrm{SD}>\mathrm{T} \geq-2,5$ $\mathrm{SD})$, dan osteopororsis ( $\mathrm{T}<-2,5 \mathrm{SD}$ ).

Data persen lemak tubuh diperoleh dari pengukuran persentase massa lemak tubuh menggunakan Bioelectrical Impedance Analysis (BIA) Transtek dengan model timbangan injak. Subjek menginjak BIA dengan posisi berdiri pandangan lurus ke depan. Subjek tidak mengenakan jaket, kaos kaki, perhiasan, dan aksesoris berbahan logam. Kategori persen lemak tubuh terdiri dari normal $(\leq 36 \%)$ dan tinggi $(>37 \%)$.

Data asupan kalsium diperoleh dari rerata asupan kalsium per hari dengan metode kuesioner semi quantitative food frequency mengenai jumlah dan frekuensi konsumsi makanan dan minuman. Hasil kuesioner diolah menggunakan program nutrisurvey kemudian dibandingkan dengan Angka Kecukupan Gizi (AKG) 2013. Asupan kalsium yang baik yaitu $1000 \mathrm{mg}$ per hari. Kategori asupan kalsium terdiri dari rendah $(<80 \%$ AKG) dan normal (80-100\% AKG).

Data asupan vitamin $\mathrm{D}$ diperoleh dari rerata asupan vitamin D per hari dengan metode kuesioner semi quantitative food frequency mengenai jumlah dan frekuensi konsumsi makanan dan minuman. Hasil kuesioner diolah menggunakan daftar kandungan vitamin D dari United States Department of Agriculture (USDA) kemudian dibandingkan dengan AKG 2013. Asupan vitamin $D$ yang baik yaitu $5 \mu$ g per hari. Kategori asupan vitamin $\mathrm{D}$ terdiri dari rendah $(<80 \% \mathrm{AKG})$ dan normal (80-100\% AKG).

Data asupan protein diperoleh dari rerata asupan protein per hari dengan metode kuesioner semi quantitative food frequency mengenai jumlah dan frekuensi konsumsi makanan dan minuman. Hasil kuesioner diolah menggunakan program nutrisurvey kemudian dibandingkan dengan AKG 2013. Asupan protein yang baik yaitu 0,8 gram per kilogram berat badan. Kategori asupan protein terdiri dari rendah $(<80 \%$ AKG) dan normal (80$100 \%$ AKG).

Data asupan lemak diperoleh dari rerata asupan lemak per hari dengan metode kuesioner semi quantitative food frequency mengenai jumlah dan frekuensi konsumsi makanan dan minuman. Hasil kuesioner diolah menggunakan program nutrisurvey kemudian dibandingkan dengan AKG 2013. Asupan lemak yang baik yaitu 60 gram per hari. Kategori asupan lemak terdiri dari rendah $(<80 \%$ AKG) dan normal (80-100\% AKG).

Data aktivitas fisik diperoleh melalui formulir International Physical Activity Questionnaire (IPAQ). Subjek menjawab beberapa pertanyaan mengenai aktivitas yang dilakukan selama 7 hari terakhir meliputi frekuensi, durasi, dan jenis kegiatan (baik kegiatan di rumah, di luar rumah, maupun waktu luang). Kategori aktivitas fisik terdiri dari moderat/ sedang (600-2999 METmenit/minggu) dan berat (>2999 METmenit/minggu).

Data dianalisis menggunakan software SPSS 21.0 for windows. Analisis univariat dilakukan untuk mendeskripsikan distribusi frekuensi lingkar pinggang, asupan kalsium, asupan protein, asupan lemak, asupan vitamin $\mathrm{D}$, aktivitas fisik, dan persen lemak tubuh. Selanjutnya dilakukan uji Chi-Square untuk menganalisis perbedaan kepadatan tulang (osteopenia dan normal) antara lingkar pinggang normal dan obesitas abdominal pada wanita. Analisis multivariat dilakukan dengan uji regresi logistik untuk mengetahui variabel yang memiliki hubungan paling kuat terhadap kepadatan tulang. 


\section{HASIL PENELITIAN}

Tabel 1. Distribusi Frekuensi Usia, Lingkar Pinggang, Asupan Kalsium, Asupan Protein, Asupan Lemak, Asupan Vitamin D, Aktivitas Fisik, dan Persen Lemak

\begin{tabular}{|c|c|c|c|c|c|}
\hline \multirow{3}{*}{ Variabel } & \multirow{3}{*}{ Kategori } & \multicolumn{4}{|c|}{ Kepadatan Tulang $(n=32)$} \\
\hline & & \multicolumn{2}{|c|}{ Osteopenia } & \multicolumn{2}{|c|}{ Normal } \\
\hline & & $\mathrm{n}$ & $\%$ & $\mathrm{n}$ & $\%$ \\
\hline Usia & $30-50$ tahun & 19 & 59,4 & 13 & 40,6 \\
\hline \multirow[t]{2}{*}{ Lingkar pinggang } & Obese & 7 & 36,8 & 9 & 69,2 \\
\hline & Normal & 12 & 63,2 & 4 & 30,8 \\
\hline \multirow[t]{2}{*}{ Asupan kalsium } & Rendah & 12 & 63,2 & 9 & 69,2 \\
\hline & Normal & 7 & 36,8 & 4 & 30,8 \\
\hline \multirow[t]{2}{*}{ Asupan protein } & Rendah & 4 & 21,1 & 3 & 23,1 \\
\hline & Normal & 15 & 78,9 & 10 & 76,9 \\
\hline \multirow[t]{2}{*}{ Asupan lemak } & Normal & 6 & 31,6 & 7 & 53,8 \\
\hline & Rendah & 13 & 68,4 & 6 & 46,2 \\
\hline \multirow[t]{2}{*}{ Asupan vitamin D } & Rendah & 17 & 89,5 & 11 & 84,6 \\
\hline & Normal & 2 & 10,5 & 2 & 15,4 \\
\hline \multirow[t]{2}{*}{ Aktivitas fisik } & Moderat & 17 & 89,5 & 6 & 46,2 \\
\hline & Berat & 2 & 10,5 & 7 & 53,8 \\
\hline \multirow[t]{2}{*}{ Persen lemak } & Tinggi & 7 & 36,8 & 9 & 69,2 \\
\hline & Normal & 12 & 63,2 & 4 & 30,8 \\
\hline
\end{tabular}

Penelitian dilakukan pada 32 wanita di Kelurahan Lamper Kidul yang memenuhi kriteria inklusi dengan usia 30-50 tahun. Tabel 1 menunjukkan subjek dengan kepadatan tulang osteopenia lebih banyak $(59,4 \%)$ jika dibandingkan subjek dengan kepadatan tulang normal (40,6\%), tidak terdapat subjek yang mengalami osteoporosis. Subjek dengan lingkar pinggang normal memiliki kepadatan tulang osteopenia sebanyak 12 orang. Sedangkan pada subjek dengan obesitas abdominal memiliki kepadatan tulang normal sebanyak 9 orang.

Subjek dengan kepadatan tulang normal yang memiliki asupan kalsium kurang dari AKG sebanyak 9 orang. Subjek dengan kepadatan tulang osteopenia memiliki asupan kalsium rendah sebanyak 12 orang. Subjek dengan kepadatan tulang osteopenia yang terpenuhi kebutuhan proteinnya sebanyak 15 orang, sedangkan pada kelompok kepadatan tulang normal sebanyak 10 orang. Subjek dengan kepadatan tulang osteopenia yang terpenuhi kebutuhan lemaknya sebanyak 6 orang, sedangkan pada kelompok kepadatan tulang normal sebanyak 7 orang. Subjek dengan kepadatan tulang osteopenia yang memiliki asupan vitamin D rendah sebanyak 17 orang, sedangkan pada kelompok kepadatan tulang normal sebanyak 11 orang.

Pada subjek dengan kepadatan tulang osteopenia sebanyak 17 orang melakukan aktivitas moderat/ sedang. Berbeda dengan subjek yang memiliki kepadatan tulang normal sebanyak 6 orang melakukan aktivitas moderat. Subjek dengan persen lemak tubuh normal memiliki kepadatan tulang osteopenia sebanyak 12 orang. Sedangkan subjek dengan persen lemak tubuh tinggi memiliki kepadatan tulang normal sebanyak 9 orang.

Tabel 2. Distribusi Frekuensi Kepadatan Tulang Berdasarkan Kategori Lingkar Pinggang

\begin{tabular}{cccccc}
\hline \multirow{2}{*}{ Variabel } & \multirow{3}{*}{ Kategori } & \multicolumn{3}{c}{ Kategori Lingkar Pinggang } \\
\cline { 3 - 6 } & & $\begin{array}{c}\text { Obesitas Abdominal } \\
(\mathrm{n}=16)\end{array}$ & Normal $(\mathrm{n}=16)$ \\
\cline { 3 - 6 } & & $\mathrm{N}$ & $\%$ & $\mathrm{n}$ & $\%$ \\
\hline Kepadatan tulang & Osteopenia & 7 & 43,8 & 12 & 75 \\
& Normal & 9 & 56,3 & 4 & 25 \\
\hline
\end{tabular}

Tabel 2 menunjukkan distribusi frekuensi kepadatan tulang antara kategori lingkar pinggang normal dan obesitas abdominal. Pada kategori lingkar pinggang normal, subjek dengan kepadatan tulang osteopenia lebih banyak (75\%) dibandingkan subjek dengan kepadatan tulang normal (25\%). Sedangkan pada kategori lingkar pinggang obesitas abdominal, subjek dengan kepadatan tulang normal lebih banyak $(56,3 \%)$ dibandingkan subjek dengan kepadatan tulang osteopenia $(43,8 \%)$. 
Tabel 3. Perbedaan Lingkar Pinggang Terhadap Kepadatan Tulang

\begin{tabular}{cccc}
\hline \multirow{2}{*}{ Variabel } & \multirow{2}{*}{$P$} & \multicolumn{2}{c}{ IK 95\% } \\
\cline { 3 - 4 } & & Min & Maks \\
\hline Lingkar pinggang & 0,072 & 0,058 & 1,164 \\
\hline
\end{tabular}

Tabel 3 menunjukkan hasil uji bivariat antara kategori lingkar pinggang dengan kategori kepadatan tulang. Berdasarkan hasil uji Chi-Square, tidak terdapat perbedaan kepadatan tulang antara kategori lingkar pinggang normal dan kategori lingkar pinggang obesitas abdominal pada wanita dewasa $(p>0,05)$. Rasio prevalensi (RP) sebesar 0,583 dengan interval kepercayaan $95 \% \quad 0,058$ sampai 1,164 .

\section{Hubungan Variabel Perancu Terhadap Kepadatan Tulang}

Tabel 4. Hubungan Variabel Perancu Terhadap Kepadatan Tulang

\begin{tabular}{lc}
\hline \multicolumn{1}{c}{ Variabel } & $p$ \\
\hline Asupan kalsium & 1 \\
Asupan protein & 1 \\
Asupan lemak & $\mathbf{0 , 2 0 8}$ \\
Asupan vitamin D & 1 \\
Aktivitas fisik & $\mathbf{0 , 0 1 5}$ \\
Persen lemak & $\mathbf{0 , 0 7 2}$ \\
\hline
\end{tabular}

Tabel 4 menunjukkan hubungan variabel perancu terhadap kepadatan tulang. Beberapa variabel perancu berhubungan dengan kepadatan tulang, yaitu asupan lemak, aktivitas fisik, dan persen lemak $(p<0,25)$. Variabel tersebut akan dimasukkan ke dalam analisis regresi logistik.

Tabel 5. Hasil Analisis Multivariat Variabel Perancu Terhadap Kepadatan Tulang

\begin{tabular}{llc}
\hline & \multicolumn{1}{c}{ Variabel } & $p$ \\
\hline Langkah 1 & Asupan lemak & 0,220 \\
& Aktivitas fisik & 0,034 \\
& Persen lemak & 0,321 \\
& Konstanta & 0,848 \\
Langkah 2 & Asupan lemak & 0,208 \\
& Aktivitas fisik & 0,014 \\
& Konstanta & 0,320 \\
Langkah 3 & Aktivitas fisik & 0,014 \\
& Konstanta & 0,118 \\
\hline
\end{tabular}

Tabel 5 menunjukkan hasil uji multivariat pada asupan lemak, aktivitas fisik, dan persen lemak. Berdasarkan hasil uji regresi logistik, aktivitas fisik memiliki hubungan paling kuat dengan kepadatan tulang wanita setelah disesuaikan dengan asupan lemak dan persen lemak $(p<0,05)$.

\section{PEMBAHASAN}

Penelitian dilakukan pada wanita dewasa dengan usia 30-50 tahun. Puncak kepadatan tulang pada wanita terjadi sekitar usia 30 tahun. Setelah mencapai puncak, kepadatan tulang cenderung menurun sebanyak $1 \%$ per tahun hingga masa menopause. ${ }^{15,16}$

Jaringan korteks dan jaringan trabekular tulang memiliki pola yang berbeda saat penuaan. Jaringan korteks menurun pada usia dewasa akhir, sedangkan jaringan trabekular menurun pada awal usia 40 tahun. Wanita premenopause kehilangan jaringan trabekular lebih besar dibanding jaringan korteks. Kehilangan jaringan korteks dan trabekular lebih cepat pada wanita menopause, meskipun jaringan trabekular menurun lebih dahulu. ${ }^{17}$

Penelitian ini menunjukkan wanita berusia 30-50 tahun cenderung mengalami penurunan kepadatan tulang. Hal ini dibuktikan dengan jumlah subjek dengan kepadatan tulang osteopenia lebih banyak $(59,4 \%)$ jika dibandingkan subjek dengan kepadatan tulang normal $(40,6 \%)$.

Risiko penurunan kepadatan tulang meningkat saat memasuki masa premenopause. Aktivitas osteoklas lebih cepat daripada osteoblas, sehingga menyebabkan penurunan kepadatan tulang. Kepadatan tulang menurun dua hingga enam kali lebih cepat saat premenopause. ${ }^{2}$ Wanita kehilangan $20 \%$ kepadatan tulang saat produksi hormon estrogen menurun sekitar $60 \% .{ }^{18}$ Hormon estrogen berfungsi sebagai regulator pertumbuhan dan homeostasis kalsium. ${ }^{16}$

Hasil penelitian ini menunjukkan tidak terdapat perbedaan kepadatan tulang antara kategori lingkar pinggang normal dan obesitas abdominal pada wanita dewasa $(p>0,05)$. Sebagian besar subjek pada kategori lingkar pinggang normal memiliki kepadatan tulang osteopenia. Sedangkan, beberapa subjek pada kategori lingkar pinggang obesitas abdominal memiliki kepadatan tulang normal. Nilai RP sebesar 0,583 dengan interval kepercayaan 95\% 0,058 sampai 1,164. Nilai RP <1 menunjukkan obesitas abdominal memiliki faktor protektif terhadap kepadatan tulang. Akan tetapi, interval kepercayaan mencakup angka 1, maka obesitas abdominal belum dapat dikatakan secara definitif sebagai faktor protektif. Hal ini dapat disebabkan oleh dua hal, yaitu obesitas abdominal memang bukan merupakan faktor protektif terhadap 
kepadatan tulang, atau jumlah subjek penelitian kurang banyak.

Obesitas abdominal berperan sebagai faktor protektif disebabkan oleh beberapa mekanisme. Obesitas abdominal memiliki berat badan yang lebih besar, sehingga memberi beban mekanis lebih besar pula. Beban mekanis tersebut merangsang pembentukan tulang dengan menurunkan apoptosis sel stroma sumsum tulang, serta meningkatkan proliferasi dan diferensiasi osteoblas. ${ }^{13}$ Obesitas terkait dengan resistensi insulin yang ditandai dengan kadar plasma insulin yang tinggi. Kadar plasma insulin tinggi memicu produksi hormon estrogen berlebih dalam ovarium. Peningkatan hormon estrogen menyebabkan penurunan aktivitas osteoklas dan peningkatan aktivitas osteoblas. ${ }^{12}$

Hasil penelitian ini bertentangan dengan penelitian yang dilakukan di Puerto Rico, menunjukkan obesitas abdominal memiliki hubungan negatif terhadap kepadatan tulang. Lemak intra-abdominal aktif secara biologis menghasilkan sitokin pro-inflamatoris, seperti IL-6 dan TNF- $\alpha$. Semakin tinggi sirkulasi konsentrasi sitokin pro-inflamatoris, maka semakin tinggi risiko patah tulang. Selain itu, produksi adiponektin menurun pada orang obesitas abdominal. Adiponektin bertugas untuk menekan osteoklastogenesis dan meningkatkan osteoblastogenesis. Adiponektin berhubungan positif terhadap kepadatan tulang. ${ }^{19}$

Akumulasi lemak intra-abdominal yang tinggi memicu jaringan adiposa mensekresi leptin dan sitokin inflamatoris. Kadar leptin yang tinggi dapat menginduksi apoptosis sel stroma sumsum tulang, menurunkan aktivitas osteoblas, dan meningkatkan aktivitas osteoklas. ${ }^{8,20}$ Ketidaknormalan produksi leptin dapat meningkatkan risiko penyakit degeneratif, seperti

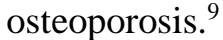

Tidak adanya perbedaan kepadatan tulang antara dua kategori lingkar pinggang memungkinkan adanya pengaruh dari variabel perancu. Beberapa variabel perancu berhubungan dengan kepadatan tulang, yaitu asupan lemak, aktivitas fisik, dan persen lemak ( $p<0,25)$. Berdasarkan hasil uji regresi logistik, aktivitas fisik memiliki hubungan paling kuat dengan kepadatan tulang wanita setelah disesuaikan dengan asupan lemak dan persen lemak $(p<0,05)$. Diketahui subjek yang memiliki kepadatan tulang normal yang melakukan aktivitas fisik berat $(53,8 \%)$ lebih banyak dibandingkan subjek yang memiliki kepadatan tulang osteopenia.

Setelah ditinjau kembali, aktivitas fisik seperti weight-bearing exercise dianjurkan untuk mencegah osteoporosis. Aktivitas fisik intensitas berat dapat meningkatkan 1\%-2\% kepadatan tulang. ${ }^{4}$ Penelitian pada 24 wanita postmenopause yang melakukan aktivitas fisik dapat mencegah penurunan kepadatan tulang lumbar spinal dan tulang femur. Intensitas aktivitas fisik berat yang dilakukan wanita premenopause akan berdampak terhadap peningkatan kepadatan tulang., ${ }^{8,21}$ Kepadatan tulang meningkat karena adanya tekanan pada tulang dari latihan menahan beban atau aktivitas fisik seperti berjalan kaki, jogging, lompat tali, naik-turun tangga, dan high-impact aerobics. ${ }^{4}$ Latihan keseimbangan dan kekuatan meningkatkan fungsi otot dan menurunkan kejadian jatuh, sehingga dapat menurunkan risiko patah tulang. Rendahnya aktivitas fisik dan gaya hidup sedentary merupakan salah satu penyebab hilangnya kepadatan tulang. ${ }^{16}$

Aktivitas fisik seperti berjalan kaki, menari, dan melompat dapat mencegah penurunan kepadatan tulang dan penurunan risiko patah tulang pinggul. ${ }^{2}$ Penelitian kohort prospektif pada 61.000 wanita postmenopause menunjukkan dengan berjalan kaki minimal 4 jam per minggu memiliki $41 \%$ risiko patah tulang pinggul lebih rendah dibandingkan dengan berjalan kaki kurang dari 1 jam per minggu. ${ }^{22}$

Subjek yang memiliki kepadatan tulang normal dengan persen lemak tinggi sebanyak $69,2 \%$. Persen lemak yang tinggi memiliki kepadatan tulang yang lebih baik. ${ }^{23}$ Hal ini bertentangan dengan penelitian cross sectional pada wanita premenopause dan postmenopause yang memiliki persen lemak tinggi berhubungan dengan osteopenia. $^{13}$

Hasil penelitian menunjukkan 69,2\% subjek yang memiliki kepadatan tulang normal tetapi asupan kalsiumnya rendah. Hal ini bertentangan dengan penelitian yang menyatakan asupan kalsium yang rendah dapat meningkatkan risiko osteoporosis dan penurunan kepadatan tulang. ${ }^{24}$ Kalsium memiliki peran penting terhadap pencegahan osteoporosis. ${ }^{25}$

Penelitian meta analisis menunjukkan asupan kalsium dapat meningkatkan kepadatan tulang sebesar $0,6 \%$ di tulang lengan, $3 \%$ di tulang spinal, dan 2,6\% di tulang femoral. ${ }^{25}$ Penurunan kepadatan tulang belakang signifikan lebih rendah pada wanita premenopause yang mengonsumsi produk susu (dengan kecukupan kalsium 900-1500 mg per hari). Selain itu, ditambahkan dengan konsumsi yoghurt signifikan menurunkan ekskresi kalsium pada urin. Risiko patah tulang $75 \%$ lebih tinggi pada wanita dengan asupan kalsium kurang dari 1200 mg per hari. Recommended Dietary 
Allowances (RDA) pada kalsium untuk wanita dewasa (31-50 tahun) adalah $1000 \mathrm{mg}$ per hari. ${ }^{2}$

Hasil penelitian menunjukkan $78,8 \%$ subjek dengan kepadatan tulang osteopenia memiliki asupan protein normal. Hal ini bertentangan dengan penelitian yang menunjukkan bahwa asupan protein yang cukup memberi dampak positif terhadap kepadatan tulang. ${ }^{26}$ Protein memberi dampak negatif apabila asupannya terlalu tinggi atau rendah mengakibatkan hilangnya kepadatan tulang. Asupan protein tinggi memiliki efek kalsiurin. ${ }^{16}$

Hasil penelitian ini menunjukkan $31,6 \%$ subjek dengan kepadatan tulang osteopenia memiliki asupan lemak normal. Asupan tinggi lemak memicu obesitas abdominal yang dapat mengganggu penyerapan kalsium di usus. Sehingga ketersediaan kalsium untuk pembentukan tulang rendah. ${ }^{13}$

Hasil penelitian ini menunjukkan $89,5 \%$ subjek dengan kepadatan tulang osteopenia memiliki asupan vitamin D yang rendah. Kepadatan tulang yang tinggi apabila didukung oleh asupan vitamin D dan kalsium yang cukup. Akan tetapi, ketersediaan makanan yang mengandung vitamin D sedikit, seperti kuning telur, ikan salmon, ikan tuna, dan minyak ikan kod. Vitamin D disintesis oleh kulit melalui paparan sinar matahari (sinar UV). Orang dewasa cenderung kekurangan vitamin D karena rendahnya intensitas terpapar sinar matahari dan tingginya persen lemak tubuh. ${ }^{16}$

Keterbatasan penelitian ini adalah terdapat variabel yang tidak diteliti seperti kadar estrogen. Hormon estrogen berperan penting terhadap homeostasis kalsium pada wanita. Serta, perbedaan letak tulang yang digunakan sebagai tempat pengukuran kepadatan tulang. Pada penelitian ini, pengukuran kepadatan tulang dilakukan pada tulang calcaneus. Namun, penelitian lain melakukan pengukuran kepadatan tulang pada tulang spinal. Rujukan untuk penelitian selanjutnya yaitu menggunakan Dual-energy X-ray Absorptiometry (DXA) karena dapat mengukur kepadatan tulang di berbagai titik tubuh.

\section{SIMPULAN}

Wanita berusia 30-50 tahun cenderung mengalami penurunan kepadatan tulang karena telah melewati puncak kepadatan tulang. Jumlah subjek dengan kepadatan tulang osteopenia lebih banyak $(59,4 \%)$ jika dibandingkan subjek dengan kepadatan tulang normal $(40,6 \%)$. Namun, tidak terdapat perbedaan kepadatan tulang antara kategori lingkar pinggang normal dan obesitas abdominal pada wanita dewasa $(p>0,05)$. Aktivitas fisik memiliki hubungan paling kuat terhadap kepadatan tulang wanita setelah disesuaikan dengan asupan lemak dan persen lemak $(p<0,05)$.

\section{SARAN}

Wanita berusia 30-50 tahun perlu meningkatkan asupan kalsium, vitamin $\mathrm{D}$, protein, dan lemak sesuai dengan AKG untuk mencegah penurunan kepadatan tulang. Wanita perlu mempertahankan persen lemak tubuh yang sesuai untuk menjaga kesehatan tulang dengan melakukan aktivitas fisik dan olahraga seperti berjalan kaki, bersepeda, dan jogging.

\section{DAFTAR PUSTAKA}

1. Prihatini S, Mahirawati VT, Jahari AB, Sudiman H. Faktor Determinan Risiko Osteoporosis di Tiga Provinsi di Indonesia. Jakarta: Media Litbang Kesehatan. 2010; XX(2): 91.

2. Tucker KL, Rosen CJ. Prevention and Management of Osteoporosis. In: Ross AC, Caballero B, Cousins RJ, Tucker KL, Ziegler TR, editors. Modern Nutrition in Health and Disease. $11^{\text {th }}$ ed. Philadelphia: Lippincott William \& Wilkins; 2012. hal. 1227-28, 1238.

3. Stenmark J, Nauroy L. The Asian Audit: Epidemiology, costs and burden of osteoporosis in Asia. Switzerland: IOF; 2009.

4. Lee RD. Osteoporosis. In: Nelms M, Sucher KP, Lacey K, Roth SL, editors. Nutrition Therapy \& Pathophysiology. $2^{\text {nd }}$ ed. USA: Wadsworth Cengage Learning; 2011. hal. 779-80.

5. Dinas Kesehatan Kota Semarang. Profil Kesehatan Kota Semarang Tahun 2012.

6. Badan Penelitian dan Pengembangan Kesehatan. Riset Kesehatan Dasar. Jakarta: Kementerian Kesehatan RI; 2010.

7. Supariasa IDN, Bakri B, Fajar I. Penilaian Status Gizi. Jakarta: EGC; 2001. hal. 191-94.

8. Gropper SS, Smith JL, Groff JL. Advanced Nutrition and Human Metabolism. $5^{\text {th }}$ ed. USA: Wadsworth Cengage Learning; 2009. hal. 283, 299

9. Lysen LK, Israel DA. Body Weight Management. In: Mahan LK, Escott-Stump S, Raymond JL, editors. Krause's Food \& The Nutrition Care Process. $13^{\text {th }}$ ed. USA: Elsevier Saunders; 2012. hal. 463-72.

10. Seidell JC, Visscher TL. Aspek Kesehatan Masyarakat pada Gizi Lebih. In: Gibney MJ, Margetts BM, Kearney JM, Arab L, editors. Gizi Kesehatan Masyarakat. Jakarta: EGC; 2009. hal. 204.

11. Hi'miyah DA, Martini S. Hubungan Antara Obesitas dengan Osteoporosis Studi di RS Husada Utama. Surabaya: Jurnal Berkala Epidemiologi. 2013; 1(2): 173-4.

12. Zhao LJ, Liu YJ, Liu PY, Hamilton J, Recker RR, Deng HW. Relationship of obesity with 
osteoporosis. Kansas: J Clin Endocrinol Metab. 2007; 92(5): 1640-1646.

13. Cao JJ. Effects of obesity on bone metabolism. USA: Journal of Orthopaedic Surgery and Research. 2011; 6: 1-7.

14. Hsu YH, Venners SA, Terwedow HA, Yan F, Tianhua N, Zhiping L, et al. Relation of body composition, fat mass, and serum lipids to osteoporotic fractures and bone mineral density in Chinese men and women. USA: Am J Clin Nutr. 2006; 83: 146-54.

15. Lee RD. Osteoporosis. In: Nelms M, Sucher KP, Lacey K, Roth SL, editors. Nutrition Therapy \& Pathophysiology. $2^{\text {nd }}$ ed. USA: Wadsworth Cengage Learning; 2011. hal. 779-80.

16. Chapman-Novakofski K. Nutrition and Bone Health. In: Mahan LK, Escott-Stump S, Raymond JL, editors. Krause's Food \& The Nutrition Care Process. $13^{\text {th }}$ ed. USA: Elsevier Saunders; 2012. hal. 531-43.

17. Reginster JY, Burlet N. Osteoporosis: A Still Increasing Prevalence. Belgia: Elsevier Bone. 2006; 38: S4-S9.

18. NOF. Hormones and Healthy Bones: Helping Midlife Women Make Better Choices for a Healthy Future. Washington DC: NOF; 2009. Available from: http://www.nof.org

19. Bhupathiraju SN, Dawson-Hughes B, Hannan MT, Lichtenstein AH, Tucker KL. Centrally Located Body Fat is Associated With Lower Bone Mineral Density in Older Puerto Rican Adults. USA: Am J Clin Nutr. 2011; 94: 1063-70.

20. Ibrahim SE, ElShishtawy HF, Helmy A, Galal ZA, Salam MHA. Serum Leptin Concentration, Bone Mineral Density, and Bone Biochemical Markers in A Sample of Egyptian Women: A Possible Relationship. Cairo: Elsevier. 2011; 33: 171-7

21. Chubak J, Ulrich CM, Tworoger SS, Sorensen B, Yasui Y, Irwin ML, et al. Effect of exercise on bone mineral density and lean mass in postmenopausal women. USA: Med Sci Sport Exerc. 2006; 38: 1236.

22. Feskanich D, Willet W, Colditz. Walking and Leisure-Time Activity and Risk of Hip-Fracture in Postmenopausal Women. USA: American Medical Association. 2002; 288: 2300-6.

23. Reid IR. Fat and Bone. New Zealand: Elsevier. 2010; 503: 20-27.

24. Varenna M, Binelli L, Casari S, Zucchi F, Sinigaglia. Effects of Dietary Calcium Intake on Body Weight and Prevalence of Osteoporosis in Early Postmenopausal Women. USA: Am J Clin Nutr. 2007; 86: 639-44.

25. Nieves JW. Osteoporosis: The Role Of Micronutrients. USA: Am J Clin Nutr. 2005; 81(suppl): 1232S-9S.

26. Darling AL, Millward DJ, Torgerson DJ, Hewitt CE, Lanham-New SA. Dietary Protein and Bone Health: A Systemic Review and Meta-Analysis. USA: Am J Clin Nutr. 2009; 90: 1674-92. 